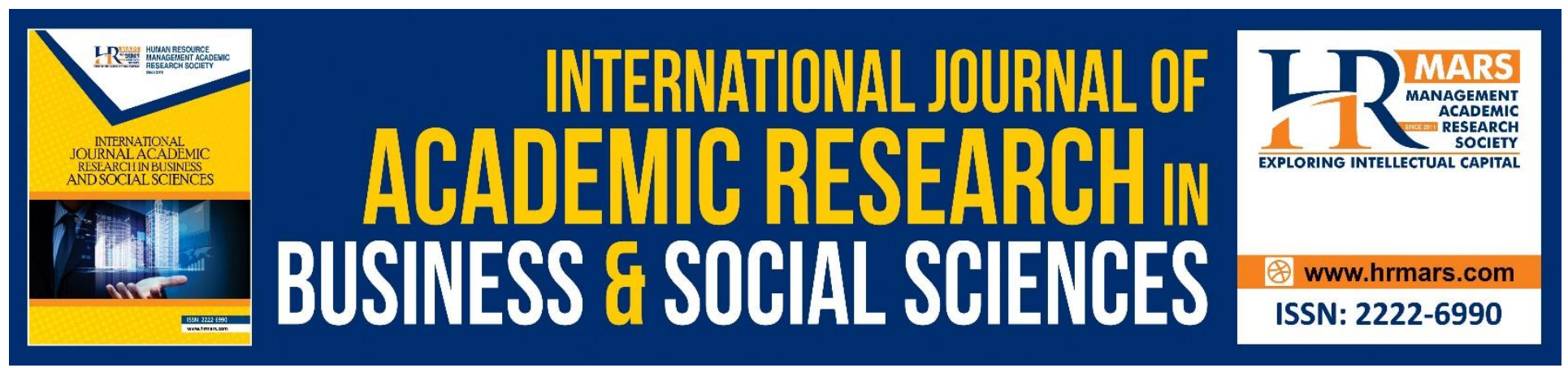

\title{
Islamic Financial Literacy: A Conceptualization and Proposed Measurement
}

Farah Amalina Md Nawi, Wan Mohd Nazri Wan Daud, Puspa Liza Ghazali, Ahmad Shukri Yazid and Zelhuda Shamsuddin

To Link this Article: http://dx.doi.org/10.6007/IJARBSS/v8-i12/5061

DOI: $10.6007 /$ IJARBSS/v8-i12/5061

Received: 08 Oct 2018, Revised: 24 Nov 2018, Accepted: 26 Dec 2018

Published Online: 29 Dec 2018

In-Text Citation: (Nawi, Daud, Ghazali, Yazid, \& Shamsuddin, 2018)

To Cite this Article: Nawi, F. A. M., Daud, W. M. N. W., Ghazali, P. L., Yazid, A. S., \& Shamsuddin, Z. (2018). Islamic Financial Literacy: A Conceptualization and Proposed Measurement. International Journal of Academic Research in Business and Social Sciences, 8(12), 629-641.

Copyright: (C) 2018 The Author(s)

Published by Human Resource Management Academic Research Society (www.hrmars.com)

This article is published under the Creative Commons Attribution (CC BY 4.0) license. Anyone may reproduce, distribute, translate and create derivative works of this article (for both commercial and non-commercial purposes), subject to full attribution to the original publication and authors. The full terms of this license may be seen

at: http://creativecommons.org/licences/by/4.0/legalcode

Vol. 8, No. 12, 2018, Pg. 629 - 641

http://hrmars.com/index.php/pages/detail/IJARBSS

JOURNAL HOMEPAGE

Full Terms \& Conditions of access and use can be found at http://hrmars.com/index.php/pages/detail/publication-ethics 


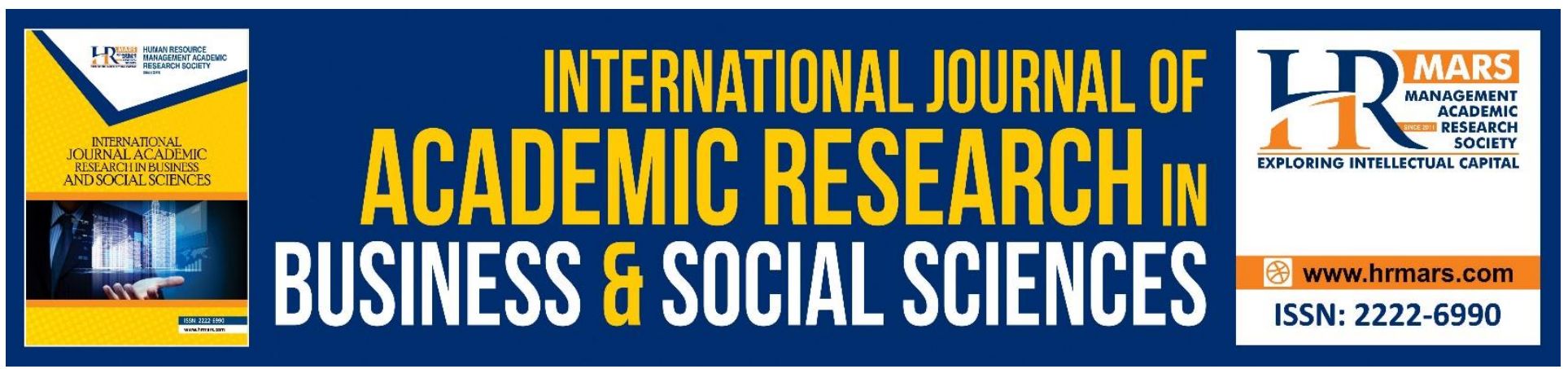

\section{Islamic Financial Literacy: A Conceptualization and Proposed Measurement}

\section{Farah Amalina Md Nawi, Wan Mohd Nazri Wan Daud, Puspa Liza Ghazali, Ahmad Shukri Yazid and Zelhuda Shamsuddin}

School of Banking and Finance, FEMS, UniSZA, Terengganu, Malaysia

\section{Abstract}

Purpose: This paper aims to scrutinize the concept of Islamic financial literacy and propose the suitable items for its measurement.

Design/methodology/approach: An exploratory study is conducted due limited existing research works are available in the area of Islamic financial literacy. The items for measurement of Islamic financial literacy in this paper consider a number of significant features of Islamic finance.

Findings: A proposed measurement items of Islamic financial literacy have been developed. Several questions are constructed and grouped namely the money basics, Islamic banking, Takaful and Shariah-compliant investments.

Research implications: This study attempts to contribute towards acquiring new theoretical models, especially in suggesting items to measure the level of Islamic financial literacy and personal financial behavior.

Practical implications: The expected outcomes from this research will highlight an idea to the Islamic financial literacy and also act as a tool in order to improve the financial behavior as guided by Shariah. Originality/value: This study is the first of this kind to advocate the items for measurement of Islamic financial literacy level by developing test questions consist of these four main aspects in Islamic finance and four elements to be measured in personal financial behavior.

Keywords: Islamic Financial Literacy, Financial Literacy, Financial Knowledge, Personal Finance, Islamic Finance

\section{Introduction}

The importance of financial literacy is undeniable especially when the Malaysian Department of Insolvency (Mdl) revealed a total of 100,610 bankruptcy cases from year 2013 to 2017 with 18,227 cases in year 2017 alone which equivalent to 50 cases each day (Bankruptcy Statistics, 2018). This condition is particularly alarming when the Credit Counselling and Debt Management Agency (AKPK) Malaysia revealed that a total of 683,169 individuals had attended financial counselling conducted 
INTERNATIONAL JOURNAL OF ACADEMIC RESEARCH IN BUSINESS AND SOCIAL SCIENCES Vol. 8, No. 12, Dec, 2018, E-ISSN: 2222-6990 @ 2018 HRMARS

by AKPK since its inception in 2006 (Hashim and Syazana, 2018) which is mostly resulted from poor financial planning (45.1\%) besides high cost of living (18.5\%) as well as other contributing factors (Kaur, 2017). The main causes of bankruptcy cases in 2017 as reported by Mdl are due to hirepurchase loan (26.4\%), personal loan (25.8\%) and housing loan (16.7\%). Inevitably, the need for bank's loan is unavoidable in financial world nowadays as people seek for financial assistance to meet their current needs in accordance to their lifestyle. Hence the major concern is not to deny the needs of borrowing, but most importantly to control and manage the debt wisely by having adequate financial knowledge and apply them accordingly.

Islam offers clear guidelines on how to appropriately manage all aspects of one's life including the financial matters. Islam clearly guides people on the financial affairs including the prohibition of any form of oppression comprising riba (interest), gharar (ambiguity), maisir (gambling) and unethical investments as well as guiding Muslims pertaining to the behaviour in spending including the importance of giving charity (zakat, sadaqah, waqaf) and the obligation to pay debts. This implies that if Muslims truly adhere to this guidance, they will be able to manage their financial matter wisely and avoid any kind of financial distress. Being literate therefore is the answer to the misconception and misbehaviour in personal finance. Earlier in the Quran, God mentions the importance of literacy as knowledge enables people to differentiate between the haq (truthfulness) and the bathil (falsehood) as stated in Surah Al An-am verse 119.

"Why should you not eat of (meats) that upon which the name of Allah has been mentioned while He has explained in detail to you what He has forbidden you, excepting that to which you are compelled. Indeed, do many lead (others) astray through their [own] inclinations without knowledge. Indeed, your Lord is most knowing of the transgressors.

Muslims are required to be knowledgeable in both religious matters and worldly affairs including being well-versed in financial dealings. As success in Islam includes being successful both in this world and in the hereafter (Al-falah), it should be emphasized that Islamic financial literacy is a religious duty for every Muslim in realization of Al-falah. Being a Muslim with high level of Islamic financial literacy literally means having an ability to understand Islamic finance concepts and inculcate good financial behaviour as guided by Shariah which will result in prudent and wise financial decisions. With the increasing number of bankruptcy cases, and bad record of personal financial report, one wonders whether Muslims understand and apply the Islamic finance principles.

Lack of literacy in Islamic finance is actually a serious threat not only to individuals but also to the survival of Islamic finance industry. The former Governor of Central Bank of Malaysia asserted several years ago that in order to make Islamic financial products be acceptable and recognizable among Malaysian, there is a dire need to enhance level of literacy on Islamic finance among population. This is necessary in order to facilitate financial transactions with a pure understanding and appreciation of the unique characteristics and features of Islamic finance and its real economic value. Customers need to be well-informed regarding the innovation in the financial market as it will lead to a better financial decision hence positively affect the investment and growth. Indeed, the 
INTERNATIONAL JOURNAL OF ACADEMIC RESEARCH IN BUSINESS AND SOCIAL SCIENCES

Vol. 8, No. 12, Dec, 2018, E-ISSN: 2222-6990 C 2018 HRMARS

consumer protection and financial literacy are vital pillars to ensure a sound and stable financial system (Lukonga, 2015), which brings us to the realization that there is pressing need for Islamic financial literacy.

\section{Literature Review}

Being literate is highly emphasized in Islam, even the first word revealed by God in the Quran is Iqra' (96:1) which means read, learn and understand. Being literate enable people to differentiate between the right and wrong and lead to guided decisions. The standard definition of literacy as developed by Literacy Definition Committee refers to the using of printed and written information to function in society, to achieve one's goals and develop one's knowledge and potential (Kirsch et al, 2001). The idea of literacy has been expanded to the various studies of particular skill sets including financial literacy in which it relates to the ability to understand and apply the financial knowledge. Financial literacy as conceptualized by Huston (2009) to have two dimensions namely understanding (financial knowledge) and use (financial application). (Figure 1).

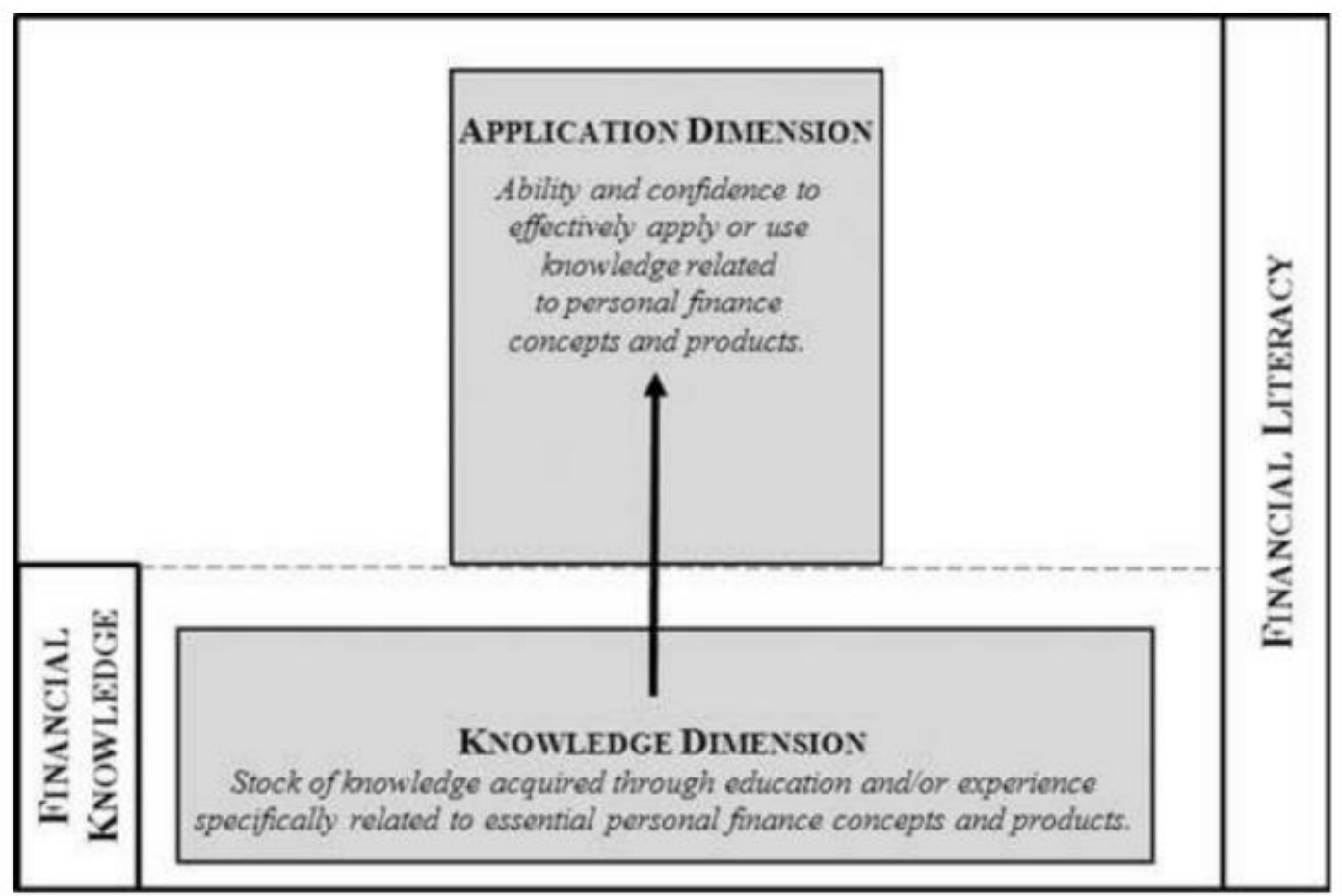

Figure 1: Concept of Financial Literacy by Huston (2009)

The literatures on Islamic financial literacy are scarce. The only definition of Islamic financial literacy is highlighted by Abdullah and Anderson (2015) which built on Huston's (2010) definition of financial knowledge stating that Islamic financial literacy means "the knowledge gained through education and/or specific experience relating to important concepts and products of Islamic finance". Due to the novelty of this definition, at present there is no universally accepted meaning of Islamic financial literacy (Abdullah and Chong, 2014). 
INTERNATIONAL JOURNAL OF ACADEMIC RESEARCH IN BUSINESS AND SOCIAL SCIENCES Vol. 8, No. 12, Dec, 2018, E-ISSN: 2222-6990 @ 2018 HRMARS

Several studies have been conducted pertaining to financial literacy. Some standard measurements of financial literacy have been established, various studies concerning on specific target groups have been conducted and most importantly the definition of financial literacy itself has been discussed thoroughly. However, very few researches conducted in respect of Islamic financial literacy and its coverage. The measurement of Islamic financial literacy needs to be strictly adhered to Islamic principles. According to Huston (2010), the content areas of financial literacy which mostly used by previous researchers are (1) basic concepts of money, (2) borrowing concepts, (3) protection concepts and (4) saving or investment concepts. Therefore, these four features will be focused in this study.

\section{Basic concept of money in Islam}

Money is the property held by man as vicegerent of God. It should be used wisely as determined by its ultimate owner, as guided by Shariah. In contrast to the core principle of conventional finance which is time has value, in which time affects the value of financial transactions, Islamic finance however prohibits interest. Personal financing products for instance forbid the borrowers to pay more than the original borrowing. Paying the interest to compensate the lender for the time during which they use the funds is totally condemned in Islam as lending money must solely for the purpose of helping, not for profits (Alhabshi, 2012). Money in Islam performs social role and should be invested to promote socio-economic justice for the benefit of ummah (community as a whole). Paying or receiving interest is prohibited as clearly stated in many verses the Quran.

"O you who have believed, do not consume usury, doubled and multiplied, but fear Allah that you may be successful." (3:130)

"And whatever you give for interest to increase within the wealth of people will not increase with Allah. But what you give in zakah, desiring the countenance of Allah, those are the multipliers." (30:39)

In contrast to conventional finance which gives the rise to more money through fixed interest payments, lending money to someone else or simply by putting it in a bank, Islamic finance considers many other important elements. The human effort, initiative and risk involved in a productive venture are equally important as the money used to finance it (Ismail, 2010). Therefore, money should be considered as potential capital rather than capital. Money becomes capital only when it is invested in business.

\section{Islamic banking products and principles}

Modern banking is based on the concept of time value of money. This concept is applied in the increments in the amount deposited by the bank's customers, as well as the increment on loan to be paid by the borrowers. Siddiqi (2004) concluded that unanimous opinion of Muslim scholars throughout history that any excess charge on loan is riba, including interest charge on loan by the banks. Islamic finance however does not reject the monetary valuation of time. For instance, the increase in loan for the price of commodity in any sale contract to be paid at a future date is not prohibited (Ahmad and Hassan, n.d). However, any financial transaction must be free from making 
INTERNATIONAL JOURNAL OF ACADEMIC RESEARCH IN BUSINESS AND SOCIAL SCIENCES

Vol. 8, No. 12, Dec, 2018, E-ISSN: 2222-6990 @ 2018 HRMARS

time value of money as an element of lending where it is claimed as a predetermined value. Islam highly encourage loan or financing to be given as it would fulfill one's need, but not for the purpose of making profit by the lender. The intention behind providing loans is only for helping the needy (Alhabshi, 2012).

As a replacement, Islamic banks introduce several interest free products and services to accommodate the banking and financing needs especially for Muslim customers. Islamic banks may use the several Shariah-compliants contracts for deposit products such as Wadiah (safekeeping), Mudharabah (profit sharing), Tawarruq (commodity murabahah) and Qard (interest free loan). Meanwhile, Shariah-compliant contracts applied for financing products includes Murabahah (markup sale), Mudharabah (profit sharing), Musyarakah (partnership), Al-Ijarah Thumma Al- Bai (hire purchase), Bai Bithaman Ajil (deferred payment sale) and Musyarakah Mutanaqisah (declining partnership) (Razak, 2012). Although Islamic banks offer several highly competitive products as the conventional banks', but the understanding of customers towards those products are still low (Mahamad and Tahir, 2010), while certain people perceive Islamic banking products as similar to the conventional counterpart (Abdullah and Rahman, 2007). Even though Islamic banking terminologies are widely and easily accessible through various mediums, apparently bank customers are not attempting to understand them better (Hamid and Nordin, 2001; and Rammal and Zurbruegg, 2006). Many Islamic financial products are still alien to some people due to the degree of information earned varying from one to the other, different understanding regarding Islamic banking operations as well as the perception towards Islamic banking concepts such as the assumptions that these products might not be Shariah-compliant or similar to the conventional products (Buchari, Rafiqi and Al Qassab, 2015). For that reasons, it is important to study how far Muslim customers really acknowledge and understand the products and services offered by Islamic banks.

\section{Takaful}

Takaful which derived from Arabic word "kafala" means to mutually guarantee. It is based on mutual intention to protect one another against financial mishap. Takaful is a protection scheme which based on the concept of mutual assistance to provide a financial security to the participants if any one of them faces any unexpected risk (Alhabshi, 2012). The related Islamic concept applied in this scheme includes tabarru' (donation), ta'awun (cooperation) with the sense of brotherhood. This is possible if the members of the group feel for themselves as much as the feel for the others. Indeed, the feeling of responsibility towards each other is being reinforced by the Islamic teachings as stated in the Quran.

"And cooperate in righteousness and piety, but do not cooperate in sin and aggression." (5:3)

Essentially, Takaful is a cooperative insurance where members are those who face the same risk or danger of incurring losses and who willingly contribute certain amount of money which knowingly will be used to compensate those members of the group who incur such losses. As the conventional insurance against certain Shariah principle for instance, the presence of the element of chance taken by the company, element of maisir (gambling) that arise out of the chance and riba 
(usury) that is present in the form of return from investment (Alhabshi, 2012), hence Islamic insurance or Takaful is needed. Of course it is because the insurance or Takaful is necessity and beneficial to the community.

\section{Shariah-Compliant Investment}

There are many types of investments vehicles including placing money in saving accounts, stocks, bonds and derivatives. However, for Muslims investors, there are several guidelines that must be adhered on order to earn profit as well as to achieve al-falah. Islamic investment must be free from element of riba (interest), maysir (gambling), gharar (ambiguity) and operations based on selling of prohibited products (ISRA, 2016). Pertaining to these principles, Usmani (1998) outlined three conditions to deal with equity shares. The first condition is Muslims are only allowed to invest in Shariah-compliant business companies. It means, investing in companies whose main business is involving interest such as conventional banks or insurance companies, or companies producing non halal products such as liquor or pork, or companies involving in gambling and pornography activities is prohibited in Islam. This prohibition covers all facets of such activities including all involved in the supply chain. The next condition is when the main business of the company complies with Shariah, but certain income of the company comes from interest-bearing account and included in the net income of the company. Pertaining to this issue, the fraction of interest income which included in dividends paid to the shareholders has to be given away and not retain by the Muslim investor. This process is called as dividend clearing and also be applied when selling the stocks. The last condition refers to non-liquid assets that must be retained in the company in which some scholars argue that the ratio on non-liquid assets must be at least 51 per cent.

In addition, Shariah-compliant investment means to be free of the elements of Gharar (uncertainty), which is regarded as gambling. The prohibition of gharar is founded on the rule of justice and fair dealings which is applied to speculative investments including trading in stock and futures markets. Moreover, investing in the company stocks that involve excessive risk is also questioned. Muslims are also only allowed to invest in ordinary shares since the preference shares are prohibited due to a predetermined rate of return offered to the investors, which would be considered as riba (interest) (Hassan and Zaher, 2001). 
INTERNATIONAL JOURNAL OF ACADEMIC RESEARCH IN BUSINESS AND SOCIAL SCIENCES

Vol. 8, No. 12, Dec, 2018, E-ISSN: 2222-6990 C 2018 HRMARS

The proposed items for measurement of Islamic financial literacy are as follow;

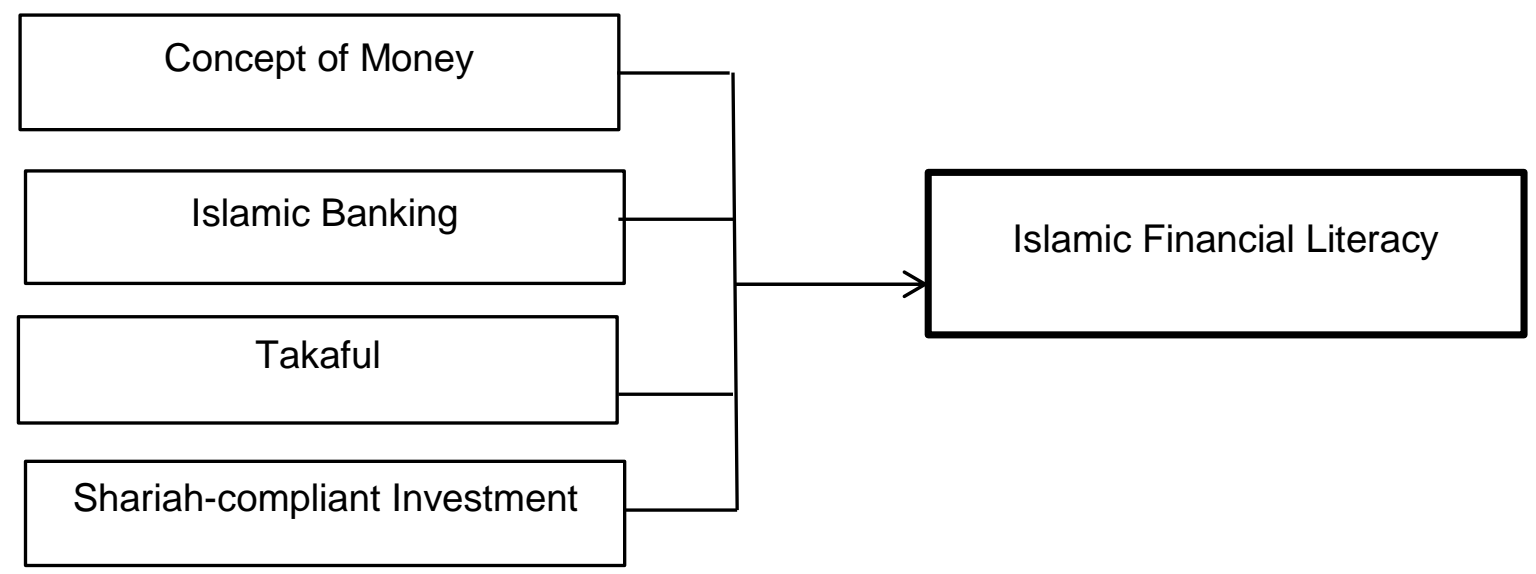

Figure 2: Proposed Measurement Items of Islamic Financial Literacy

\section{Method}

\section{Research Design}

In this paper, an exploratory research is going to be conducted because limited existing research works are available in the area of Islamic financial literacy and a literature review will be conducted to better explain the research area.

There are various methods of measuring financial literacy. Previous studies on financial literacy mostly covers the aspects of investment concepts (69\%), basic concepts of money (63\%), borrowing concepts (52\%) and financial protection concept or insurance which is 33\% (Huston, 2010). In this study, researcher decides to focus on these areas by adhering to the Shariah compliance principles. Therefore, the items for measurement of Islamic financial literacy developed in this study focus on four aspects namely money basics, Islamic banking products, Takaful and Islamic investment. As these measurement items need to be tested, Churchill (1979) structured framework has been applied by following the steps below: 


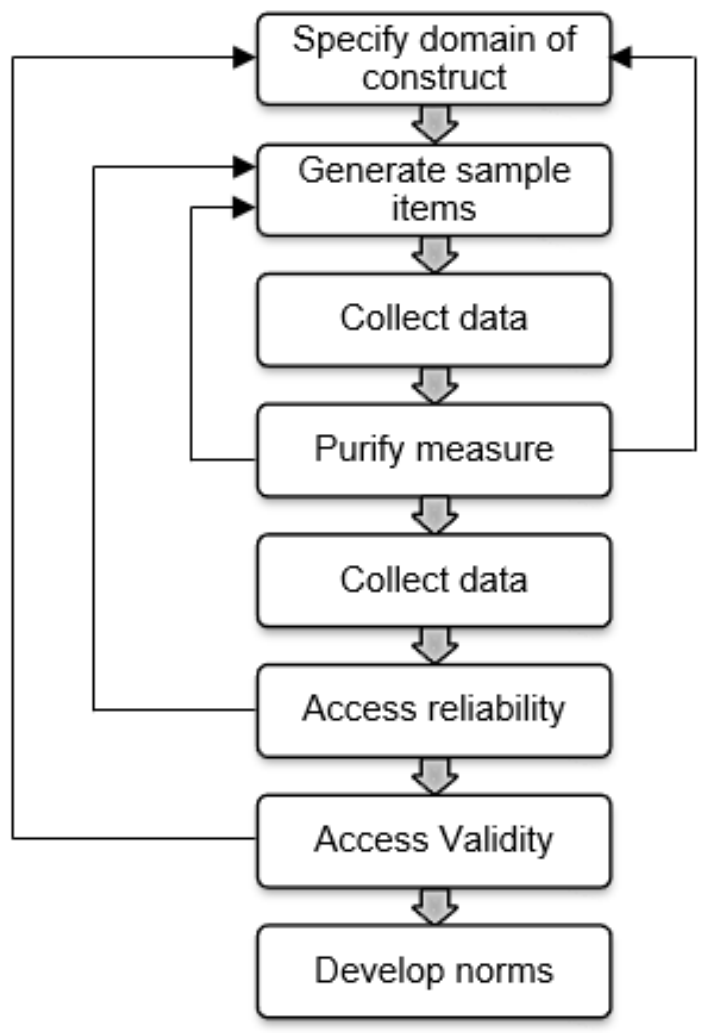

Literature search

Literature search

Focus group

Coefficient alpha

Factor Analysis

Coefficient alpha

Split-half reliability

Dultitrait multimethod matrix

Criterion validity

Average and other statistics

summarizing distribution of scores

\section{Proposed Measurement for Islamic Financial Literacy}

As this study focuses on the four areas which are mostly covered by previous researchers, several related questions have been designed and tailored to the Islamic finance perspective. The summary of the items and questions developed depicted in Table 1.

Table 1: Islamic Financial Literacy Question Items

\begin{tabular}{|c|c|c|c|c|}
\hline & & True & False & $\begin{array}{l}\text { Not } \\
\text { Sure }\end{array}$ \\
\hline \multicolumn{5}{|c|}{ Money Basics } \\
\hline 1. & Any excess or interest charge on loan is "riba". & & & \\
\hline 2. & Paying or receiving interest is prohibited in Islam. & & & \\
\hline 3. & $\begin{array}{l}\text { Lending money must be for the purpose of helping, not for the } \\
\text { profit. }\end{array}$ & & & \\
\hline 4. & $\begin{array}{l}\text { Money can only be generated through lawful trade and } \\
\text { investment where parties share the risks and rewards. }\end{array}$ & & & \\
\hline 5. & Money is not a commodity but a medium of exchange. & & & \\
\hline 6. & $\begin{array}{l}\text { Human effort, initiative and risks must be considered to earn } \\
\text { profit. }\end{array}$ & & & \\
\hline
\end{tabular}




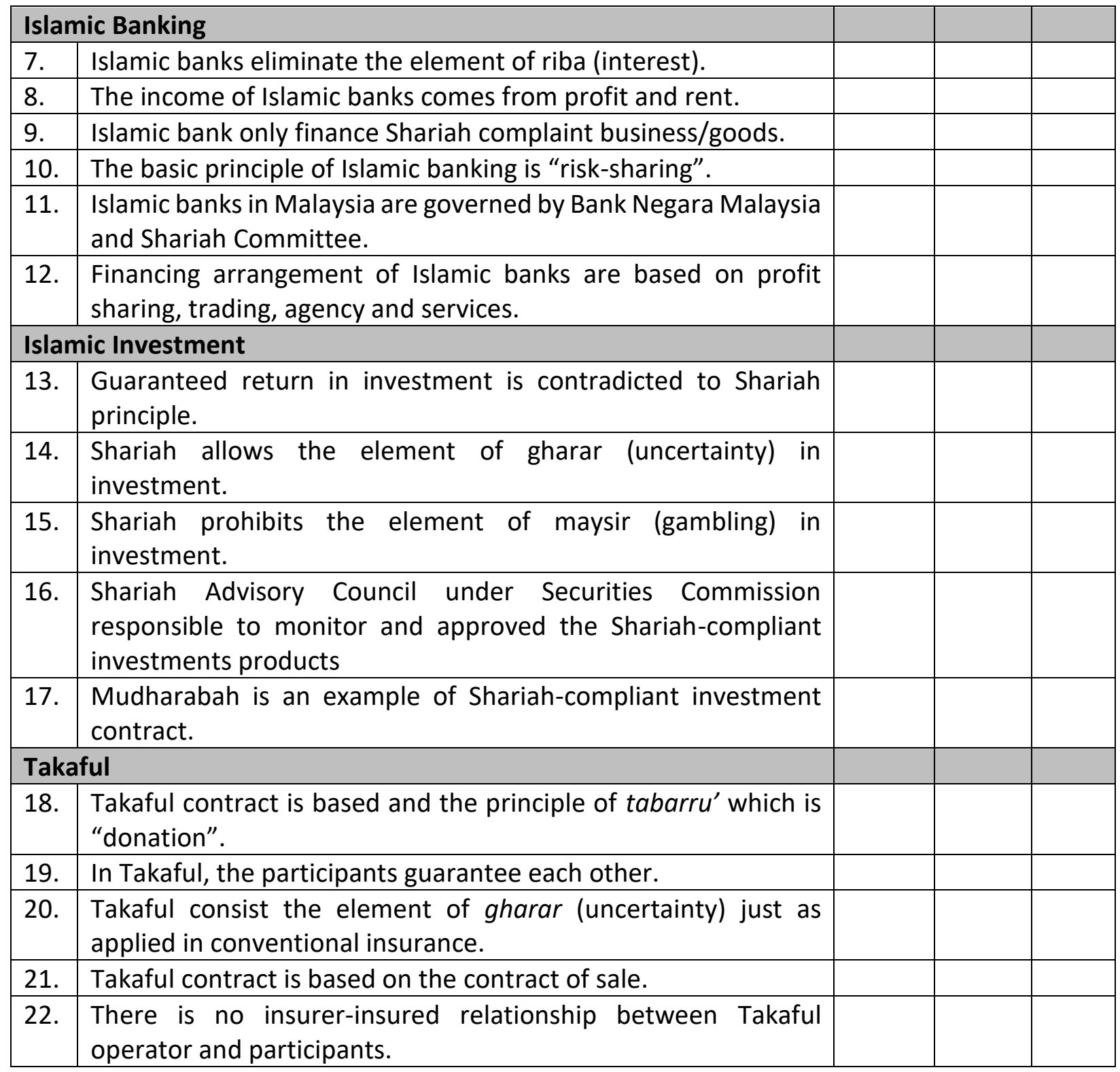

A set of questionnaire will be distributed to the respondents to evaluate the level of Islamic financial literacy among them. 1 point will be given for the correct answer, while 0 point for wrong answer in which the total point will be sum up to compute the total score. The score will then be graded to determine whether the level of Islamic financial literacy among respondents is low, medium or high.

\section{Conclusion}

Financial literacy is one of the central concerns as it is about individual's understanding on personal finance, which leads to wise financial decisions. Islamic finance which governs by the Shariah (Islamic law) determines the ways of conducting all the financial transactions including buying and selling, 
spending, saving, borrowing as well as investment and financial protection. It is assumes that when a person is literate on Islamic finance, they will behave in accordance to Shariah and prudently in spending. This paper proposes four important areas for measurement of Islamic financial literacy namely money basics, Islamic banking, Takaful and Shariah-compliant investments. The proposed measurement for Islamic Financial Literacy is likely to be useful in order to understand the level of literacy among consumers. Islamic finance is regarded as the remedy that cures people from the financial illness as there are such clear guidelines regarding individuals' financial affairs, revealed by the God - the creator.

\section{Acknowledgements}

We would like to express special gratitude and appreciation to the provider of research grant, Universiti Sultan Zainal Abidin for funding under the University Research Grant UniSZA/2017/DPU/67 and to everyone who involved directly and indirectly in providing ideas and fruitful resources in completing this research.

\section{References}

Abdul Razak, S.H. (2012). Deposits and financing operations of Islamic banks (2nd ed.). Kuala Lumpur, Malaysia: INCEIF

Abdullah, M.A., and Anderson, A. (2015). Islamic financial literacy among bankers in Kuala Lumpur, Journal of Emerging Economies and Islamic Research, 3 (2).

Abdullah, M.A., and Chong, R. (2014). Financial literacy: An exploratory review of the literature and future research, Journal of Emerging Economies and Islamic Research, 2 (3).

Abdullah. R.F.S. and Abdul Rahman, A.R. (2007). Factors influencing knowledge of Islamic banking services: the case of Malaysian bank managers, Review of Islamic Economics. 11 (2), 31-54.

Ahmad, U.F., and Hassan, F.K. (n.d.). The time value concept of Islamic finance, The American Journal of Islamic Social Sciences, 23 (1).

AIF. (2015). Finance Matter: Understanding Gen Y. Kuala Lumpur, Malaysia.

Alhabshi, S.O. (2012). Wealth planning and management (2nd ed.). Kuala Lumpur, Malaysia: INCEIF.

Al-Tamimi, H.A and Kalli, A.A (2009). Financial literacy and investment decisions of UAE investors, The Journal of Risk Finance, 10:5, 500-516.

Al-Quran

Bankruptcy Statistics December 2017. (2018). Retrieved from http: // www.mdi.gov.my/index.php/ about-us/resources/statistics/bankruptcy/1233-bankruptcy-statistic-december-2017

Bateman, H.J., Ebling, C., Geweke, J., Louviere, J.J., Satchell, S.E., and Thorp, S.J. (2010). Economic rationality, risk presentation and retirement portfolio choice, CenSoC Working Paper, 10 (4).

Bley, J. and Kuehn, K. (2004). Conventional versus Islamic finance: Student knowledge and perception in the United Arab Emirates. International Journal of Islamic Financial Services, 5(4),17-30.

Buchari, I., Rafiki, A. and Al Qassab M.A.H. (2015). Awareness and attitudes of employees towards Islamic banking products in Bahrain, Procedia Economics and Finance 30 ( 2015 ), 68 - 78

Chen, H., and Volpe, R., (1998). An analysis of personal financial literacy among college students, Financial Services Review, 7(2), 107-128 
INTERNATIONAL JOURNAL OF ACADEMIC RESEARCH IN BUSINESS AND SOCIAL SCIENCES

Vol. 8, No. 12, Dec, 2018, E-ISSN: 2222-6990 @ 2018 HRMARS

Chen, H., and Volpe, R.P., (2002). Gender differences in personal financial literacy among college students, Financial Services Review, 11(3), 289-307.

Churchill, G.A. (1979). A paradigm for developing better measures of marketing constructs, Journal of Marketing Research, 16, 64-73.

Ergun, K. (2017). Financial literacy among university students: A study in eight European countries, International journal of consumer studies. 42 (2), 15. https://doi.org/10.1111/ijcs.12408

Hamid, A. H., and Nordin, N. A. (2001). A Study on Islamic banking education and strategy for the new millennium - Malaysian Experience, International Journal of Islamic Financial Services, 2(4).

Haron, S., Ahmad, N., and Planisek, S. L. (1994). Bank patronage factors of Muslim and non-Muslim customers, International Journal of Bank Marketing, 12(1), 32-40. http://dx.doi.org/10.1108/02652329410049599

Hashim, S. and Syazana, I. (2018). AKPK - Advancing prudent financial behaviour. Consumer and Market Conduct Department March 2018. Retrieved from http://www.bnm.gov.my/index.php?ch=en_publicationandpg=en_work_papersandac=69and $\mathrm{bb}=$ file

Hayhoe, C.R., Leach, L., Allen, M.W. and Edwards, R. (2005). Credit cards held by college students, Financial Counseling and Planning, 16(1).

Hogarth, J. M. (2002). Financial literacy and family. Journal of Family and Consumer Sciences, 94, 112.

Hassan, T.S. and Zaher, M.K. (2001). A comparative literature survey of Islamic finance and banking, Financial Markets, Institutions and Instruments, 10 (4), pp. 155-99.

Huston, S.J. (2010). Measuring financial literacy, Journal of Consumer Affairs 44 (2), 296 - 316.

Huston, S.J. (2009). The Concept and Measurement of Financial Literacy: Preliminary Results from a New Survey on Financial Literacy Assessment. Proceedings of Academy of Financial Services Annual Conference, CA: Anaheim.

Imelda, C. M., Angeline, M. P., Gwendelina, A. V. and Genalen, M.P. (2017). Financial literacy of professional and pre-service teachers in the Philippines, Global Journal of Economics, 5 (3). doi: 10.4172/2375-4389.1000267

Ismail, A.G. (2010). Money, Islamic bank and the real economy (1st ed). Singapore: Cengage Learning Asia Pte Ltd

ISRA. (2016). Islamic financial system: Principles and operations (2 ${ }^{\text {nd }}$ ed). Kuala Lumpur, Malaysia: ISRA.

Kaur, D. (2017). AKPK Resolves RM593m worth of Debt Cases. Themalaysianreserve. Retrieved from https: //themalaysianreserve.com/2017/10/12/ akpk-resolves-rm593m-worth-debt-cases/

Kirsch, I., Yamamoto,K., Norris, N., et al. (2001). Technical report and data file user's manual for the 1992 national adult literacy survey. NCES 2001-457. Washington, DC: U.S. Department of Education, National Center for Education Statistics.

Loo, M. (2010). Attitudes and perceptions towards Islamic Banking among Muslims and non-Muslims in Malaysia: Implications for marketing to baby boomers and X-generation, International Journal of Arts and Sciences.

Lukonga, I. (2015). IMF Working Paper: Islamic finance, consumer protection and financial stability. Retrieved from: https://www.imf.org/external/pubs/ft/wp/2015/wp15107. 
INTERNATIONAL JOURNAL OF ACADEMIC RESEARCH IN BUSINESS AND SOCIAL SCIENCES

Vol. 8, No. 12, Dec, 2018, E-ISSN: 2222-6990 @ 2018 HRMARS

Mahamad, M., and Tahir, I. M. (2011). Perception of non-Muslims towards Islamic banking: A pilot dtudy, Journal of Humanitarian, 16.

Mandell, L., and Klein, L. S. (2009). The impact of financial literacy education on subsequent financial behaviour, Journal of Financial Counseling and Planning, 20(1), 15-24.

Marimuthu, M., Wai Jing, C., Phei Gie, L., Pey Mun, L., and Yew Ping, T. (2010). Islamic banking: Selection criteria and implications. Global Journal of Human-Social Science Research, 10(4).

Moore, D. (2003). Survey of financial literacy in Washington State: Knowledge, behavior, attitudes, and experiences. Technical Report n. 03-39, Social and Economic Sciences Research Center, Washington State University.

Nayebzadeh, S., Taft, M. K., and Sadrabadi, M.M. (2013).The Study of University Professors' Financial Literacy, International Journal of Academic Research in Accounting, Finance and Management Sciences, 3(3), 111-117.

OECD (2017). G20/OECD INFE Report. Ensuring Financial Education and Consumer Protection for All in The Digital Age. Retrieved from http://www.oecd.org/daf/fin/ financial-education /G20OECD-INFE-Report-Financial-Education-Consumer-Protection-in-the-digital-age.pdf

Ramdhony, D. (2013). Islamic Banking Awareness Attitudes and Bank Selection Criteria, International Journal of Humanities and Applied Sciences (IJHAS), 2(2), 29-35.

Rammal, H. G., and Zurbruegg, R. (2007). Awareness of Islamic banking products among Muslims: The case of Australia, Journal of Financial Services Marketing, 12(1), 65-74. http://dx.doi.org/10.1057/palgrave.fsm.4760060

Rooij, M. V., Lusardi, A., and Alessie, R. (2011). Financial literacy and retirement planning in the Netherlands, Journal of Economic Psychology, 32(4), 593-608.

Sekaran, U., 2003. Research methods for business - A skill-building approach. 4th ed. New York: John Wiley and Sons, Inc.

Shafii, Z., Yusoff Z.M., and Noh, S.M. (2013). Islamic financial planning and wealth management $\left(1^{\text {st }}\right.$ ed). Kuala Lumpur: IBFIM.

Shim, S., Barber, B.L., Card, N.A., Xiao, J.J. and Serido, J.(2010). Financial Socialization of First-Year College Students: The Roles of Parents, Work and Education, Journal of Youth Adolescence, 39(1), 457-470.

Siddiqi, M. N. (2004). Riba, bank interest and rational behind its prohibition. Islamic Research and Training Institute in Jeddah.

Usmani, T.M. (1998). An introduction to Islamic finance. New Delhi. Idara Isha'at-E-Diniyat.

Yew, S.Y., Yong,C.C., Cheong, K.C. and, Tey, N.P. (2017). Does Financial Education Matter? Education Literacy among Undergraduates in Malaysia. Institutions and Economies. 9(1), 43-60.

Zarcadoolas, C., Pleasant, A.F., and Greer, D.S. (2006). Advancing Health Literacy: A Framework for Understanding and Action. San Francisco: Jossey-Bass. 